\title{
(6) OPEN ACCESS \\ The molecular targets of approved treatments for pulmonary arterial hypertension
}

\author{
Marc Humbert, ${ }^{1,2,3}$ Hossein-Ardeschir Ghofrani ${ }^{4,5}$
}

${ }^{1}$ Service de Pneumologie, DHU Thorax Innovation, Assistance Publique-Hôpitaux de Paris, Hôpital Bicêtre, Paris, France ${ }^{2}$ Université Paris-Sud, Laboratoire d'Excellence en Recherche sur le Médicament et Innovation Thérapeutique, Paris, France

${ }^{3}$ INSERM Unité 999, Le Kremlin-Bicêtre, Paris, France ${ }^{4}$ University of Giessen and Marburg Lung Center (UGMLC), member of the German Center of Lung Research (DZL), Giessen, Germany

${ }^{5}$ Department of Medicine, Imperial College London, London, UK

\section{Correspondence to}

Professor Marc Humbert, Service de Pneumologie, Assistance Publique-Hôpitaux de Paris, DHU Thorax Innovation, Hôpital Bicêtre 78 Rue du Général Leclerc, Le Kremlin-Bicêtre, Paris 94275, France; marc.humbert@abc.aphp.fr

Received 10 April 2015 Revised 23 June 2015 Accepted 29 June 2015 Published Online First 28 July 2015

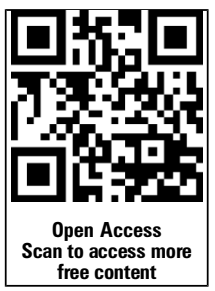

CrossMark

To cite: Humbert $M$, Ghofrani H-A. Thorax 2016;71:73-83.

\section{ABSTRACT}

Until recently, three classes of medical therapy were available for the treatment of pulmonary arterial hypertension (PAH) — prostanoids, endothelin receptor antagonists and phosphodiesterase type 5 (PDE5) inhibitors. With the approval of the soluble guanylate cyclase stimulator riociguat, an additional drug class has become available targeting a distinct molecular target in the same pathway as PDE5 inhibitors. Treatment recommendations currently include the use of all four drug classes to treat PAH, but there is a lack of comparative data for these therapies. Therefore, an understanding of the mechanistic differences between these agents is critical when making treatment decisions. Combination therapy is often used to treat PAH and it is therefore important that physicians understand how the modes of action of these drugs may interact to work as complementary partners, or potentially with unwanted consequences. Furthermore, different patient phenotypes mean that patients respond differently to treatment; while a certain monotherapy may be adequate for some patients, for others it will be important to consider alternating or combining compounds with different molecular targets. This review describes how the four currently approved drug classes target the complex pathobiology of PAH and will consider the distinct target molecules of each drug class, their modes of action, and review the pivotal clinical trial data supporting their use. It will also discuss the rationale for combining drugs (or not) from the different classes, and review the clinical data from studies on combination therapy.

\section{BACKGROUND}

Pulmonary arterial hypertension (PAH) is a chronic, potentially fatal disease characterised haemodynamically by increased mean pulmonary artery pressure $\geq 25 \mathrm{~mm} \mathrm{Hg}$, normal pulmonary artery wedge pressure $\leq 15 \mathrm{~mm} \mathrm{Hg}$ and elevated pulmonary vascular resistance (PVR) $>3$ Wood Units. PAH is caused by progressive remodelling of the pulmonary vasculature by cell proliferation and fibrosis, occluding the blood vessels and ultimately leading to right ventricular failure and death. ${ }^{1-3}$ The vascular pathology of PAH results at least in part from endothelial cell dysfunction, accompanied by impaired signalling in several pathways. ${ }^{4-9}$ Despite advances in current therapies for $\mathrm{PAH}$, there is still a significant unmet medical need, as the mortality of patients with $\mathrm{PAH}$ remains high. ${ }^{10-12}$

Until recently, three classes of medical therapy were available for the treatment of PAH targeting three dysfunctional pathways-prostanoids, endothelin receptor antagonists (ERAs) and phosphodiesterase type 5 (PDE5) inhibitors. With the approval of the soluble guanylate cyclase (sGC) stimulator riociguat, ${ }^{13-16}$ a new, fourth class of therapy has become available, targeting the same pathway as PDE5 inhibitors. The treatment algorithm discussed at the 5th World Symposium on Pulmonary Hypertension $(\mathrm{PH})^{17}$ recommends the use of all four drug classes to treat PAH (table 1), as do the recently published CHEST guidelines on pharmacological therapy for PAH in adults (table 2).$^{18}$ However, there is a lack of comparative data for these therapies; therefore, an understanding of the mechanistic differences between these agents and the clinical data sets supporting their use is critical when making treatment decisions.

Inter-individual differences mean that patients can respond differently to the same PAH treatment. Monotherapy may be adequate for some patients, while others may only improve when treated with a combination of two or three different classes of drugs. Although it is unclear whether these patients are benefiting from combination therapy, or whether the use of more than one drug is increasing the patient's chances of receiving the treatment to which they are most responsive, for patients who receive combination therapy, it is important to consider alternating or combining compounds with different molecular targets. Combination therapy is often used to treat PAH and it is important, therefore, that physicians understand how the modes of action of these drugs might result in additive, synergistic or antagonistic interactions which could lead to differences in safety and efficacy.

This review will give a comprehensive overview of the available approved medical treatments for $\mathrm{PAH}$, describing how each drug class targets the complex pathobiology of $\mathrm{PAH}$, and will consider the distinct target molecules of each drug class. We will also discuss the rationale for combination therapy and review the clinical evidence for the use of combination therapy.

\section{Currently approved therapies and their molecular targets}

The modes of action of the approved classes of therapy for $\mathrm{PAH}$ are illustrated in figure 1. Key positive clinical trial data for each therapy are summarised in tables 3 and 4 .

\section{Prostanoids: stimulation of adenylate cyclase through prostacyclin (IP) receptor agonism}

Prostaglandin $\mathrm{I}_{2}\left(\mathrm{PGI}_{2}\right)$ or prostacyclin is a potent pulmonary vasodilator synthesised in the endothelium. ${ }^{36}$ Its main target, the IP receptor, is expressed in the vascular smooth muscle cell (VSMC) layer of the pulmonary vasculature ${ }^{37-39}$ as well as other tissues. Activation of the IP receptor results in the conversion of ATP to cyclic AMP (cAMP) which 
Table 1 Treatment recommendations from the 5th World Symposium on Pulmonary Hypertension ${ }^{17}$

\begin{tabular}{|c|c|c|c|c|}
\hline \multicolumn{5}{|c|}{ Initial therapy with PAH approved drugs } \\
\hline Recommendation & Evidence* & WHO FC II & WHO FC III & WHO FC IV \\
\hline 1 & $A$ or $B$ & $\begin{array}{l}\text { Ambrisentan } \\
\text { Bosentan } \\
\text { Macitentan } \\
\text { Riociguat } \\
\text { Sildenafil } \\
\text { Tadalafil }\end{array}$ & $\begin{array}{l}\text { Ambrisentan } \\
\text { Bosentan } \\
\text { Epoprostenol intravenous } \\
\text { lloprost inhaled } \\
\text { Macitentan } \\
\text { Riociguat } \\
\text { Sildenafil } \\
\text { Tadalafil } \\
\text { Treprostinil subcutaneous, inhaled } t\end{array}$ & Epoprostenol intravenous \\
\hline Ila & $C$ & & $\begin{array}{l}\text { lloprost intravenoust } \\
\text { Treprostinil intravenous }\end{array}$ & $\begin{array}{l}\text { Ambrisentan } \\
\text { lloprost inhaled, intravenoust } \\
\text { Macitentan } \\
\text { Riociguat } \\
\text { Sildenafil, tadalafil } \\
\text { Treprostinil subcutaneous, intravenous, inhaledt }\end{array}$ \\
\hline $\mathrm{Ilb}$ & B & & Beraprost $†$ & \\
\hline & $\mathrm{C}$ & & Initial combination therapy & Initial combination therapy \\
\hline $\begin{array}{l}\text { Reprinted with perm } \\
\text { Level definition: } \\
\text { A: Data derived from } \\
\text { B: Data derived from } \\
\text { C: Consensus of opir } \\
\text { Results on the basis } \\
\text { Classes of recommen } \\
\text { Class I: Evidence an } \\
\text { Class II: Conflicting } \\
\text { Class Ila: Weight of } \\
\text { Class IIb: Usefulness } \\
\text { Class III: Evidence or } \\
\text { *Level of evidence is } \\
\text { †Approved only: by } \\
\text { FDA, US Food and D }\end{array}$ & $\begin{array}{l}\text { n Elsevier. } \\
\text { randomised cli } \\
\text { randomised clir } \\
\text { e experts and/o } \\
\text { o and subgrou } \\
\text { al agreement t } \\
\text { and/or a diverg } \\
\text { pinion is in fa } \\
\text { less well esta } \\
\text { ggreement that } \\
\text { the WHO FC } \\
\text { reprostinil inha } \\
\text { nistration; PAH }\end{array}$ & $\begin{array}{l}\text { or meta-analyse } \\
\text { or large non-ranc } \\
\text { udies, retrospecti } \\
\text { s of clinical trials } \\
\text { n treatment or p } \\
\text { inion about the } \\
\text { efulness/efficacy. } \\
\text { evidence/opinior } \\
\text { treatment or pro } \\
\text { ority of patients } \\
\text { ew Zealand (ilop } \\
\text { ry arterial hypert }\end{array}$ & $\begin{array}{l}\text { dies. } \\
\text { registries. } \\
\text { do not meet the criteria of a level of } \\
\text { beneficial, useful, effective. Is recomme } \\
\text { efficacy of the given treatment or proce } \\
\text { considered. } \\
\text { onsidered. } \\
\text { ot useful/effective, and in some cases } \\
\text { les. } \\
\text { nous); in Japan and South Korea (berap } \\
\text { O FC, WHO functional class. }\end{array}$ & $\begin{array}{l}\text { dicated. } \\
\text { nful. Is not recommended. }\end{array}$ \\
\hline
\end{tabular}

increases protein kinase A (PKA) activity, leading to downstream effects including vasodilation. Prostacyclin has antithrombotic, antiproliferative, antimitogenic and immunomodulatory properties. $^{38}$ 40-42 Prostacyclin synthase and prostacyclin metabolites are reduced in the pulmonary vasculature and blood serum of patients with $\mathrm{PH} .{ }^{43}{ }^{44}$ The prostanoid drugs are synthetic analogues of prostacyclin, designed to substitute the endogenous prostacyclin that is lacking in these patients.

\section{Epoprostenol}

Epoprostenol is a synthetic salt of $\mathrm{PGI}_{2}$, and was the first prostanoid to be tested in patients with PAH. ${ }^{19}$ It is approved in the USA, Europe and several other regions for treatment of $\mathrm{PAH}$ in patients in WHO functional class (WHO FC) III and IV, who do not respond adequately to conventional therapy. Epoprostenol is unstable, with a half-life of $<5 \mathrm{~min}$, and is administered intravenously via an indwelling central venous catheter connected to

Table 2 Summary of CHEST/American College of Chest Physicians guidelines for pharmacological treatment of PAH ${ }^{18}$

\begin{tabular}{|c|c|c|c|}
\hline Patient status* & WHO FC II & WHO FC III & WHO FC IV \\
\hline Treatment naïve & $\begin{array}{l}\text { Monotherapy with any approved } \\
\text { ERA, PDE5i or riociguat }\end{array}$ & $\begin{array}{l}\text { Monotherapy with any approved ERA, } \\
\text { PDE5i or riociguat }\end{array}$ & $\begin{array}{l}\text { Monotherapy with } \\
\text { parenteral prostanoid }\end{array}$ \\
\hline $\begin{array}{l}\text { Treatment naïve, unable or unwilling to receive parenteral } \\
\text { prostanoids }\end{array}$ & - & - & $\begin{array}{l}\text { Inhaled prostanoid plus } \\
\text { ERA }\end{array}$ \\
\hline $\begin{array}{l}\text { Treatment naïve with evidence of rapid disease progression } \\
\text { or markers of poor prognosis }\end{array}$ & - & $\begin{array}{l}\text { Initial monotherapy with parenteral } \\
\text { prostanoid or subcutaneous treprostinil }\end{array}$ & - \\
\hline $\begin{array}{l}\text { Receiving one or two oral therapies with evidence of rapid } \\
\text { disease progression or markers of poor prognosis }\end{array}$ & - & $\begin{array}{l}\text { Addition of parenteral or inhaled } \\
\text { prostanoid }\end{array}$ & - \\
\hline Receiving ERA or PDE5i but remains symptomatic & - & Addition of inhaled prostanoid & - \\
\hline $\begin{array}{l}\text { Receiving established monotherapy, with unacceptable } \\
\text { clinical status }\end{array}$ & - & \multicolumn{2}{|c|}{$\begin{array}{l}\text { Add inhaled prostanoids to stable ERA/PDE5i } \\
\text { Add sildenafil to epoprostenol } \\
\text { Add riociguat to bosentan, ambrisentan or inhaled prostanoid } \\
\text { - Add macitentan to PDE5i }\end{array}$} \\
\hline $\begin{array}{l}\text { Receiving dual combined therapy, with unacceptable } \\
\text { clinical status }\end{array}$ & - & \multicolumn{2}{|c|}{$\begin{array}{l}\text { Add a third class of therapy. Patient should ideally be treated at an } \\
\text { expert centre }\end{array}$} \\
\hline
\end{tabular}

*Pharmacotherapy is not recommended for patients with WHO FC I.

ERA, endothelin receptor antagonist; PAH, pulmonary arterial hypertension; PDE5i, phosphodiesterase 5 inhibitor; WHO FC, WHO functional class. 

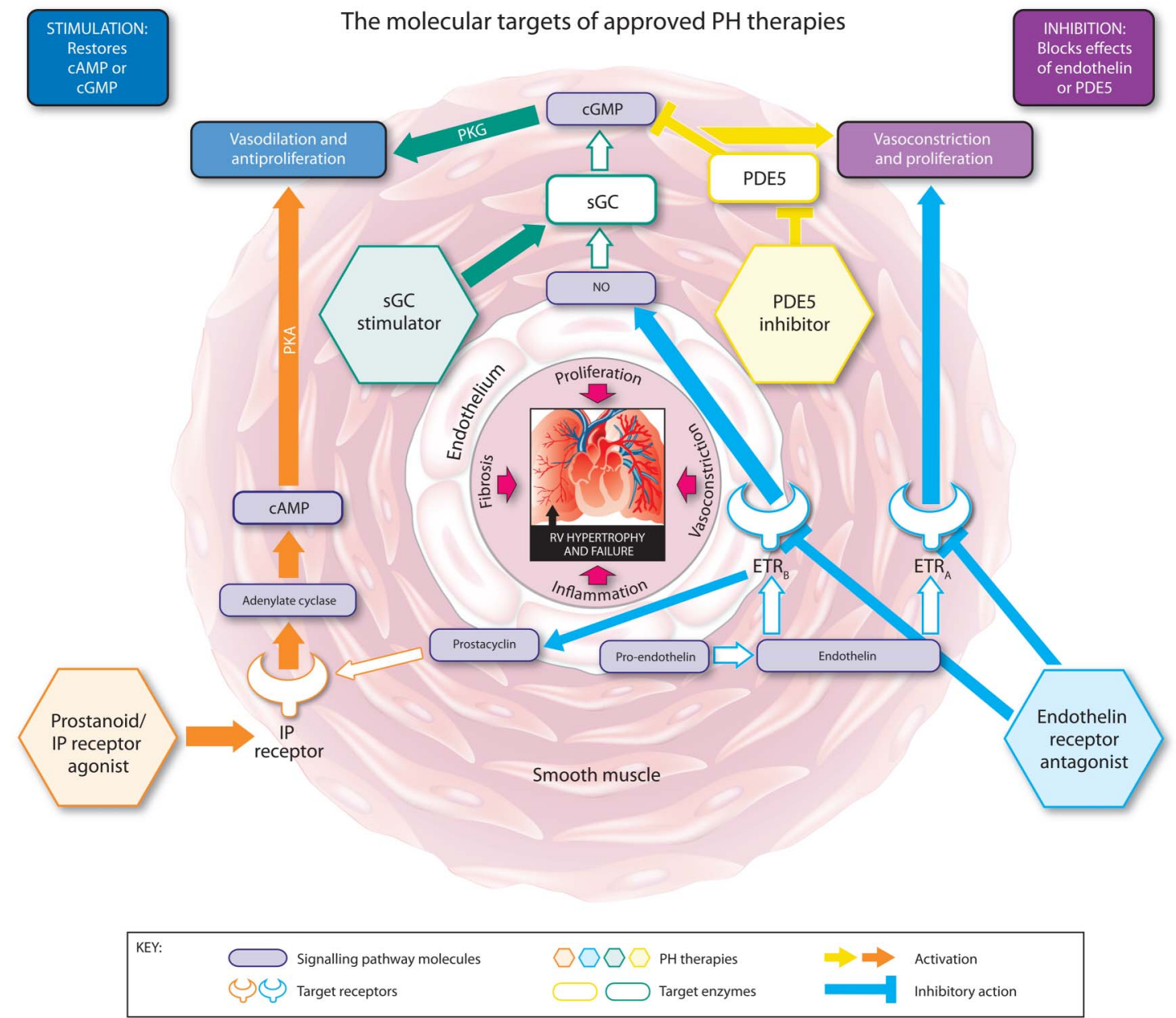

Figure 1 The molecular targets, signalling pathways, and modes of action of approved pulmonary hypertension (PH) therapies. cAMP, cyclic adenosine monophosphate; $c G M P$, cyclic guanosine monophosphate; ETR ${ }_{A}$, endothelin receptor $A$; ETR $B_{B}$, endothelin receptor B; IP, prostacyclin; NO, nitric oxide; PDE5, phosphodiesterase type 5; PKA, phosphate kinase A; PKG, CGMP-dependent protein kinase; SGC, soluble guanylate cyclase.

an infusion pump. As such, meticulous hygiene must be observed due to the risk of catheter site infection. Interruption of drug supply can result in severe and potentially fatal rebound PH. ${ }^{45}{ }^{46}$ In 2008, a novel formulation was introduced (Veletri, Actelion Pharmaceuticals Ltd, Allschwil, Switzerland) that is stable at room temperature for up to $24 \mathrm{~h}$, eliminating the need for ice packs to cool the pump. Details of the randomised trial of epoprostenol are listed in table 3.

\section{Iloprost}

Iloprost is a carbacyclin analogue of $\mathrm{PGI}_{2}$ that has improved stability at room temperature and a longer half-life (20-30 min) compared with epoprostenol. It can be administered intravenously or by inhalation. Inhaled iloprost is approved in the USA for patients with PAH in WHO FC II or III, and in Europe and several other countries for patients with PAH in WHO FC III. Details of the AIR study of inhaled iloprost are listed in table 3. Intravenous iloprost treatment has been evaluated in several open-label uncontrolled clinical studies, however not in a randomised controlled clinical trial, and is only approved in New Zealand for PAH.

\section{Beraprost}

Beraprost is a prostanoid with a half-life of $35-40 \mathrm{~min}$ that is administered orally. Although treatment with beraprost initially improved 6 min walking distance (6MWD) (ALPHABET study, table 3), ${ }^{24}$ long-term follow-up showed that the improvement was not sustained. ${ }^{47}$ Beraprost is approved in Japan, South Korea and some other South-East Asian countries such as Indonesia for treatment of PAH in patients in WHO FC III.

\section{Treprostinil}

Treprostinil is an analogue of $\mathrm{PGI}_{2}$ which has a longer half-life (up to $4 \mathrm{~h}$ ) and improved stability compared with epoprostenol. It can be administered via subcutaneous, intravenous, inhaled and oral routes. Subcutaneous treprostinil is approved in the USA for the treatment of patients with PAH in WHO FC II-IV, and in Europe for patients with PAH in WHO FC III. Intravenous treprostinil should be reserved for patients who are intolerant of the subcutaneous route, patients with a preference for intravenous administration, or in whom the risks are considered warranted. Inhaled and oral treprostinil are only approved in the USA, and oral treprostinil is only approved in treatment-naïve patients with $\mathrm{PAH}$, whereas inhaled treprostinil is only approved for use in combination therapy. Details of the randomised trials of subcutaneous, inhaled (TRIUMPH I) and oral treprostinil (FREEDOM-M) are listed in table 3.

\section{Selexipag}

Selexipag is a selective, non-prostanoid IP receptor agonist. It is rapidly metabolised to an active form with a half-life of $7.9 \mathrm{~h}$, 
Table 3 Positive randomised controlled trials of PAH therapies

\begin{tabular}{|c|c|c|c|c|c|c|}
\hline Trial name & Treatment & Trial duration & Number/type of patients & Primary endpoint met & $\begin{array}{l}\text { Secondary endpoint } \\
\text { significant } \\
\text { improvements }\end{array}$ & Adverse events \\
\hline $\begin{array}{l}\text { Treatment of primary PH with } \\
\text { continuous intravenous prostacyclin } \\
\text { (epoprostenol) }{ }^{19}\end{array}$ & $\begin{array}{l}\text { Continuous intravenous } \\
\text { epoprostenol at doses } \\
\text { determined during baseline } \\
\text { catheterisation or } \\
\text { conventional treatment (mean } \\
\text { dose } 7.9 \pm 2.7 \mathrm{ng} / \mathrm{kg} / \mathrm{min} \text { ) }\end{array}$ & $\begin{array}{l}8 \text { weeks followed by } \\
\text { non-randomised } \\
\text { treatment for up to } \\
18 \text { months }\end{array}$ & $\begin{array}{l}19 \text { patients with primary PH. } 10 \\
\text { patients received epoprostenol and } \\
9 \text { received only anticoagulants, } \\
\text { oral vasodilators and diuretics }\end{array}$ & $\begin{array}{l}\text { Total pulmonary resistance }-7.9 \\
\text { units }(95 \% \mathrm{Cl}-13.1 \text { to }-2.2) \text { at } \\
8 \text { weeks, sustained for up to } \\
18 \text { months }\end{array}$ & Mean PAP & $\begin{array}{l}\text { Complications attributable to } \\
\text { administration method }\end{array}$ \\
\hline $\begin{array}{l}\text { Continuous subcutaneous infusion of } \\
\text { treprostinil, a prostacyclin analogue, } \\
\text { in patients with pulmonary arterial } \\
\text { hypertension }^{20}\end{array}$ & $\begin{array}{l}\text { Continuous, subcutaneously } \\
\text { infused treprostinil up to } \\
22.5 \mathrm{ng} / \mathrm{kg} / \mathrm{min}\end{array}$ & 12 weeks & $\begin{array}{l}470 \text { patients with PH, either } \\
\text { primary or associated with CTD or } \\
\text { congenital systemic-to-pulmonary } \\
\text { shunts }\end{array}$ & $\begin{array}{l}\text { Change from baseline in } 6 \mathrm{MWD} \text { at } \\
12 \text { weeks. Median treatment } \\
\text { difference }+16 \mathrm{~m}(95 \% \mathrm{Cl} 4.4 \text { to } \\
27.6)\end{array}$ & $\begin{array}{l}\text { Haemodynamics, } \\
\text { symptoms score, QoL }\end{array}$ & $\begin{array}{l}\text { Infusion-site pain, infusion-site } \\
\text { reaction, infusion-site bleeding, } \\
\text { headache, diarrhoea, nausea, jaw } \\
\text { pain, flushing, lower limb oedema, } \\
\text { gastrointestinal haemorrhage }\end{array}$ \\
\hline $\begin{array}{l}\text { Double-blind placebo-controlled } \\
\text { clinical investigation into the efficacy } \\
\text { and tolerability of inhaled treprostinil } \\
\text { sodium in patients with severe } \\
\text { pulmonary arterial hypertension } \\
\text { (TRIUMPH I) })^{21}\end{array}$ & $\begin{array}{l}\text { Inhaled treprostinil (up to } \\
54 \mu \mathrm{g} \text { ) four times daily }\end{array}$ & 12 weeks & 235 patients with PAH & $\begin{array}{l}\text { Peak change from baseline in } 6 \mathrm{MWD} \\
\text { at } 12 \text { weeks. Median treatment } \\
\text { difference }+20 \mathrm{~m} \mathrm{(95 \%} \mathrm{Cl} 8.0 \text { to } \\
32.8)\end{array}$ & QoL, NT-proBNP & $\begin{array}{l}\text { Cough, headache, nausea, } \\
\text { dizziness, flushing, throat } \\
\text { irritation, pharyngolaryngeal pain, } \\
\text { diarrhoea }\end{array}$ \\
\hline $\begin{array}{l}\text { Efficacy and safety of oral treprostinil } \\
\text { monotherapy for the treatment of } \\
\text { pulmonary arterial hypertension } \\
\text { (FREEDOM-M) }\end{array}$ & $\begin{array}{l}\text { Oral treprostinil } 0.25-12 \mathrm{mg} \\
\text { twice daily }\end{array}$ & 12 weeks & $\begin{array}{l}349 \text { treatment-naïve patients with } \\
\text { PAH }\end{array}$ & $\begin{array}{l}\text { Change from baseline in } 6 \mathrm{MWD} \text { at } \\
12 \text { weeks. Median treatment } \\
\text { difference }+23 \mathrm{~m}(95 \% \mathrm{Cl} 4 \text { to } 41)\end{array}$ & Borg dyspnoea score & $\begin{array}{l}\text { Headache, nausea, diarrhoea, jaw } \\
\text { pain }\end{array}$ \\
\hline $\begin{array}{l}\text { The aerosolised iloprost randomised } \\
\text { study (AIR) }\end{array}$ & $\begin{array}{l}\text { Inhaled iloprost } 2.5 \mu \mathrm{g} \text { or } \\
5 \mu \mathrm{g} \text { six or nine times daily; } \\
\text { median inhaled dose } 30 \mu \mathrm{g} \\
\text { per day }\end{array}$ & 12 weeks & $\begin{array}{l}203 \text { patients with mixed types of } \\
\text { PH }\end{array}$ & $\begin{array}{l}\text { An increase of at least } 10 \% \text { in } \\
6 \mathrm{MWD} \text { and } 1 \text { NYHA FC at } 12 \text { weeks. } \\
16.8 \% \text { of iloprost patients vs } 4.9 \% \\
\text { of placebo patients achieved the } \\
\text { primary endpoint }\end{array}$ & $\begin{array}{l}\text { Haemodynamics, Borg } \\
\text { dyspnoea score, QoL }\end{array}$ & $\begin{array}{l}\text { Increased cough, flushing, jaw } \\
\text { pain }\end{array}$ \\
\hline $\begin{array}{l}\text { Arterial PH and beraprost European } \\
\text { trial (ALPHABET) }{ }^{24}\end{array}$ & $\begin{array}{l}\text { Beraprost sodium } 20-120 \mu \mathrm{g} \\
\text { four times daily }\end{array}$ & 12 weeks & 130 patients with $\mathrm{PAH}$ & $\begin{array}{l}\text { Change from baseline in } 6 \mathrm{MWD} \text { at } \\
12 \text { weeks. Mean treatment } \\
\text { difference }+25.1 \mathrm{~m}(95 \% \mathrm{Cl} 1.8 \text { to } \\
48.3)\end{array}$ & Borg dyspnoea score & $\begin{array}{l}\text { Headache, flushing, jaw pain, } \\
\text { diarrhoea }\end{array}$ \\
\hline $\begin{array}{l}\text { Bosentan randomised trial of } \\
\text { endothelin antagonist therapy } \\
(\text { BREATHE-1) }\end{array}$ & $\begin{array}{l}\text { Bosentan } 62.5 \mathrm{mg} \text { three times } \\
\text { daily for } 4 \text { weeks, increased to } \\
125 \text { or } 250 \mathrm{mg} \text { three times } \\
\text { daily for } 12 \text { weeks }\end{array}$ & 16 weeks & $\begin{array}{l}213 \text { treatment-naïve patients with } \\
\text { either IPAH or PAH-CTD }\end{array}$ & $\begin{array}{l}\text { Change from baseline in } 6 \mathrm{MWD} \text { at } \\
16 \text { weeks. Mean treatment } \\
\text { difference }+44 \mathrm{~m}(95 \% \mathrm{Cl} 21 \text { to } 67)\end{array}$ & $\begin{array}{l}\text { WHO FC, Borg } \\
\text { dyspnoea score, TTCW }\end{array}$ & $\begin{array}{l}\text { Headache, dizziness, worsening } \\
\text { PAH }\end{array}$ \\
\hline $\begin{array}{l}\text { Endothelin antagonist trial in mildly } \\
\text { symptomatic pulmonary arterial } \\
\text { hypertension patients (EARLY) }\end{array}$ & $\begin{array}{l}\text { Bosentan } 62.5 \mathrm{mg} \text { three times } \\
\text { daily, increasing to } 125 \mathrm{mg} \\
\text { three times daily after } \\
4 \text { weeks }\end{array}$ & 6 months & 185 patients with WHO FC II PAH & $\begin{array}{l}\text { PVR at rest at } 6 \text { months, expressed } \\
\text { as a percentage of the baseline } \\
\text { value and change from baseline in } \\
6 \mathrm{MWD} \text { at } 6 \text { months. Treatment } \\
\text { difference }-22.6 \% \text { ( } 95 \% \mathrm{Cl}-33.5 \text { to } \\
-10.0) \text { for PVR, and }+19.1 \mathrm{~m}(95 \% \\
\mathrm{Cl} 3.6 \text { to } 41.8) \text { for } 6 \mathrm{MWD} \text {. } 6 \mathrm{MWD} \\
\text { endpoint not significant }\end{array}$ & $\begin{array}{l}\text { TTCW, NT-proBNP, } \\
\text { QoL }\end{array}$ & $\begin{array}{l}\text { Nasopharyngitis, abnormal liver } \\
\text { function tests }\end{array}$ \\
\hline
\end{tabular}




\section{Table 3 Continued}

\begin{tabular}{|c|c|c|c|c|c|c|}
\hline Trial name & Treatment & Trial duration & Number/type of patients & Primary endpoint met & $\begin{array}{l}\text { Secondary endpoint } \\
\text { significant } \\
\text { improvements }\end{array}$ & Adverse events \\
\hline $\begin{array}{l}\text { Ambrisentan in pulmonary arterial } \\
\text { hypertension, randomised, } \\
\text { double-blind, placebo-controlled, } \\
\text { multicentre, efficacy (ARIES-1 and } \\
\text { ARIES-2) }\end{array}$ & $\begin{array}{l}\text { Ambrisentan ARIES-1, } 5 \text { or } \\
10 \mathrm{mg} \text { once daily; ARIES-2, } \\
2.5 \text { or } 5 \mathrm{mg} \text { once daily }\end{array}$ & 12 weeks & $\begin{array}{l}202 \text { (ARIES-1) and } 192 \text { (ARIES-2) } \\
\text { patients with PAH }\end{array}$ & $\begin{array}{l}\text { Change from baseline in } 6 \mathrm{MWD} \text { at } \\
\text { week } 12 \text {. Mean treatment difference } \\
+45 \mathrm{~m}(95 \% \mathrm{Cl} 24 \text { to } 65) \text { for } 5 \mathrm{mg} \\
\text { combined; }+32 \mathrm{~m}(95 \% \mathrm{Cl} 2 \text { to } 63) \\
\text { for } 2.5 \mathrm{mg} \text { and }+51 \mathrm{~m}(95 \% \mathrm{Cl} 27 \\
\text { to } 76) \text { for } 10 \mathrm{mg}\end{array}$ & $\begin{array}{l}\text { ARIES-1: WHO FC, } \\
\text { Borg dyspnoea score, } \\
\text { BNP } \\
\text { ARIES-2: TTCW, QoL, } \\
\text { Borg dyspnoea score, } \\
\text { BNP }\end{array}$ & $\begin{array}{l}\text { Peripheral oedema, headache, } \\
\text { nasal congestion }\end{array}$ \\
\hline $\begin{array}{l}\text { Study with an endothelin receptor } \\
\text { antagonist in pulmonary arterial } \\
\text { hypertension to improve clinical } \\
\text { outcome (SERAPHIN) }{ }^{28}\end{array}$ & $\begin{array}{l}\text { Macitentan } 3 \mathrm{mg} \text { or } 10 \mathrm{mg} \\
\text { once daily }\end{array}$ & $\begin{array}{l}\text { Event-driven study, } \\
\text { median duration } \\
115 \text { weeks }\end{array}$ & $\begin{array}{l}742 \text { treatment-naïve or pretreated } \\
\text { patients with PAH }\end{array}$ & $\begin{array}{l}\text { Time from initiation of treatment to } \\
\text { first occurrence of a composite } \\
\text { morbidity or mortality endpoint. HR } \\
\text { vs placebo } 0.7 \text { ( } 97.5 \% \mathrm{Cl} 0.52 \text { to } \\
0.96) \text { for } 3 \mathrm{mg} ; 0.55(97.5 \% \mathrm{Cl} 0.39 \\
\text { to } 0.76 \text { ) for } 10 \mathrm{mg}\end{array}$ & $\begin{array}{l}\text { 6MWD, WHO FC, } \\
\text { haemodynamics }\end{array}$ & $\begin{array}{l}\text { Headache, nasopharyngitis, } \\
\text { anaemia }\end{array}$ \\
\hline $\begin{array}{l}\text { Sildenafil use in pulmonary arterial } \\
\text { hypertension (SUPER) }{ }^{29}\end{array}$ & $\begin{array}{l}\text { Sildenafil } 20,40 \text { or } 80 \mathrm{mg} \\
\text { three times daily }\end{array}$ & 12 weeks & $\begin{array}{l}278 \text { treatment-naïve patients with } \\
\text { IPAH, PAH-CTD or with repaired } \\
\text { congenital systemic-to-pulmonary } \\
\text { shunts }\end{array}$ & $\begin{array}{l}\text { Change from baseline in } 6 \mathrm{MWD} \text { at } \\
\text { week } 12 \text {. Mean treatment difference } \\
+45 \mathrm{~m}(99 \% \mathrm{Cl} 21 \text { to } 70) \text { for } 20 \mathrm{mg} \text {; } \\
+46 \mathrm{~m}(99 \% \mathrm{Cl} 20 \text { to } 72) \text { for } 40 \mathrm{mg} \text {; } \\
+50 \mathrm{~m}(99 \% \mathrm{Cl} 23 \text { to } 77) \text { for } 80 \mathrm{mg}\end{array}$ & $\begin{array}{l}\text { Mean PAP, WHO FC, } \\
\text { haemodynamics }\end{array}$ & Headache, flushing, dyspepsia \\
\hline $\begin{array}{l}\text { Tadalafil in the treatment of } \\
\text { pulmonary arterial hypertension } \\
\text { (PHIRST-1) }\end{array}$ & $\begin{array}{l}\text { Tadalafil } 2.5,10,20 \text { or } 40 \mathrm{mg} \\
\text { once daily }\end{array}$ & 16 weeks & $\begin{array}{l}405 \text { treatment-naïve or pretreated } \\
\text { patients with PAH }\end{array}$ & $\begin{array}{l}\text { Change from baseline in } 6 \mathrm{MWD} \text { at } \\
\text { week } 16 \text {. Mean treatment difference } \\
+33 \mathrm{~m}(95 \% \mathrm{Cl} 15 \text { to } 50) \text {. Endpoint } \\
\text { not met in pretreated patients }\end{array}$ & $\begin{array}{l}\text { Mean PAP, PVR, } \\
\text { cardiac index, QoL }\end{array}$ & Headache, myalgia, flushing \\
\hline $\begin{array}{l}\text { Pulmonary arterial hypertension } \\
\text { soluble guanylate cyclase-stimulator } \\
\text { trial } 1 \text { (PATENT-1) }\end{array}$ & $\begin{array}{l}\text { Riociguat } 1.5 \mathrm{mg} \text { or } 2.5 \mathrm{mg} \\
\text { three times daily }\end{array}$ & 12 weeks & $\begin{array}{l}443 \text { treatment-naïve or pretreated } \\
\text { patients with PAH }\end{array}$ & $\begin{array}{l}\text { Change from baseline in } 6 \mathrm{MWD} \text { at } \\
\text { week } 12 \text {. Mean treatment difference } \\
+36 \mathrm{~m}(95 \% \mathrm{Cl} 20 \text { to } 52)\end{array}$ & $\begin{array}{l}\text { Haemodynamics, } \\
\text { NT-proBNP, WHO FC, } \\
\text { TTCW, Borg dyspnoea } \\
\text { score }\end{array}$ & $\begin{array}{l}\text { Headache, dizziness, dyspepsia, } \\
\text { hypotension, peripheral oedema }\end{array}$ \\
\hline
\end{tabular}

6MWD, 6 min walking distance; BNP, B-type natriuretic peptide; IPAH, idiopathic PAH; NT-proBNP, N-terminal prohormone of brain natriuretic peptide; NYHA FC, New York Heart Association functional class; PAH, pulmonary arterial hypertension; PAH-CTD, PAH associated with connective tissue disease; PAP, pulmonary arterial pressure; PH, pulmonary hypertension; PVR, pulmonary vascular resistance; QoL, quality of life; TTCW, time to clinical worsening; WHO FC, WHO functional class. 
and is administered orally. It is not yet approved in the USA or Europe. Following a phase II study in 43 patients, ${ }^{48}$ the recent GRIPHON phase III event-driven study in 1156 patients indicated that treatment with selexipag significantly decreased the relative risk of a morbidity/mortality event compared with placebo. At the time of writing this article, the results of the GRIPHON trial have only been presented in abstract form. ${ }^{49} 50$

\section{Blockade of endothelin receptors}

Endothelin 1 (ET-1) is a potent vasoconstrictor and promoter of pulmonary artery smooth muscle cell proliferation ${ }^{51}$ which is upregulated in PAH. ${ }^{52}$ There are two ET-1 receptor subtypes: endothelin receptors $\mathrm{A}\left(\mathrm{ET}_{\mathrm{A}} \mathrm{R}\right)$ and $\mathrm{B}\left(\mathrm{ET}_{\mathrm{B}} \mathrm{R}\right) . \mathrm{ET}_{\mathrm{A}} \mathrm{R}$ is highly expressed in VSMCs and contributes to ET-1-induced contraction and proliferation of VSMCs in PAH. ${ }^{53}{ }^{54} \mathrm{ET}_{\mathrm{B}} \mathrm{R}$ is predominantly expressed in vascular endothelial cells where activation with ET-1 promotes vasodilation through accelerated production of $\mathrm{PGI}_{2}$ and nitric oxide (NO) and clearance of ET-1, ${ }^{55-57}$ but is also expressed in VSMCs, where it has vasoconstrictive and proliferative actions. ${ }^{55}$ ET receptors are also upregulated in PAH. ${ }^{51}$ The dual ERAs bosentan and macitentan, and the selective $\mathrm{ET}_{\mathrm{A}} \mathrm{R}$ antagonist ambrisentan bind and block the ET receptors, preventing ET-1-mediated responses.

\section{Bosentan}

Bosentan is a dual ERA, administered orally. It is approved for the treatment of patients with PAH in WHO FC II-IV in the USA and several other regions, and in patients in WHO FC II-III in Europe. It may be associated with increased levels of liver transaminases; therefore patients are started on a low dose, which is up-titrated to the therapeutic dose as long as liver transaminase levels remain normal. Monthly monitoring of liver transaminases is mandatory for patients taking bosentan. ${ }^{58}$ Details of the BREATHE-1 and EARLY studies are given in table 3.

\section{Ambrisentan}

Ambrisentan is a selective $\mathrm{ET}_{\mathrm{A}} \mathrm{R}$ antagonist with a longer half-life than bosentan ( $9 \mathrm{~h}$ vs $5.4 \mathrm{~h}$, respectively), administered orally. It is approved for the treatment of patients with $\mathrm{PAH}$ in WHO FC II and III in the USA, Europe and several other regions. Theoretically, selective $\mathrm{ET}_{\mathrm{A}} \mathrm{R}$ antagonists should be more effective than dual ERAs in that they only target the vasoconstrictive and mitogenic activities of ET-1- $\mathrm{ET}_{\mathrm{A}} \mathrm{R}$, while preserving the vasodilatory and antimitogenic effect of ET-1-ET ${ }_{B} R .{ }^{59}$ Despite its selectivity for $\mathrm{ET}_{\mathrm{A}} \mathrm{R}$, ambrisentan has not shown greater efficacy in non-comparative monotherapy clinical trials, compared with bosentan. ${ }^{60}$ This may be because the distribution or function of $\mathrm{ET}_{\mathrm{B}} \mathrm{R}$ is altered in disease states, and thus dual receptor blockers appear to perform as well as those ERAs with a specific target. ${ }^{61}$ Unlike bosentan, ambrisentan was not associated with elevated liver toxicity, ${ }^{62}$ but peripheral oedema was reported more frequently compared with placebo. ${ }^{27}$ Details of the ARIES- 1 and ARIES-2 trials are given in table 3, and the ARIES-E extension study is detailed in table 4.

\section{Macitentan}

Macitentan is a dual receptor ERA, administered orally. It is approved for the treatment of $\mathrm{PAH}$ for the long-term treatment of WHO FC II and III patients with PAH in the USA and Europe. Macitentan was not associated with liver toxicity. ${ }^{28}$ Decreased haemoglobin levels have been reported more frequently in patients receiving macitentan versus placebo in randomised controlled trials. Details of the SERAPHIN study are given in table 3. 


\section{Inhibition of phosphodiesterase-5}

The PDE superfamily of enzymes inactivates and degrades cyclic guanosine monophosphate (cGMP) and cAMP, important vasoactive mediators that, via activation of cGMP-dependent protein kinase $(\mathrm{PKG})$ and $\mathrm{PKA}$, trigger vasodilation and inhibit proliferation (PKG can also be activated by increasing levels of cAMP). PDE5 is abundantly expressed in the VSMCs of the pulmonary vasculature and is upregulated in PAH in the VSMCs, and in right ventricle (RV) cardiomyocytes. ${ }^{63-66}$ The upregulation of PDE5 results in increased hydrolysis of cGMP. The PDE5 inhibitors sildenafil and tadalafil occupy the catalytic site on PDE5, blocking the degradation of cGMP. ${ }^{67}$ PDE5 inhibitors prevent cGMP degradation but are dependent on cGMP synthesis and the presence of NO. ${ }^{68}{ }^{69}$ However, there is also evidence to suggest that the beneficial effects of PDE5 inhibition in PH are influenced by natriuretic peptide activity and the presence of natriuretic peptide-derived cGMP. ${ }^{70}$

\section{Sildenafil}

Sildenafil is an oral PDE5 inhibitor approved for the treatment of patients with PAH in WHO FC II-III in Europe and WHO FC II-IV in the USA. The details of SUPER-1 and SUPER-2, the long-term extension are given in tables 3 and 4.

\section{Tadalafil}

Tadalafil is an oral PDE5 inhibitor with a longer half-life than sildenafil, allowing once-daily dosing, rather than the three times daily dose that is indicated with sildenafil. It is approved in the USA, Europe and several other countries for the treatment of patients with PAH in WHO FC II-III. Details of the PHIRST-1 study and its long-term extension PHIRST-2 are given in tables 3 and 4 .

\section{Stimulation of $s G C$}

sGC is expressed in the VSMCs of the pulmonary vasculature, platelets, RV and other tissues. When bound to NO, sGC catalyses the conversion of GTP to $\mathrm{CGMP}^{71}{ }^{72}$ promoting vasodilation and inhibiting smooth muscle proliferation, leucocyte recruitment, inflammation, fibrosis, platelet aggregation and vascular remodelling via several downstream mechanisms. ${ }^{73}$ The sGC stimulator riociguat is the first member of this novel class of therapeutics. ${ }^{69} 73-75$

\section{Riociguat}

Riociguat is an oral sGC stimulator with a dual mode of action. It sensitises sGC to endogenous $\mathrm{NO}$ by stabilising NO-sGC binding. Riociguat also directly stimulates sGC, independently of $\mathrm{NO}^{73}{ }^{69}$ resulting in increased generation of cGMP. ${ }^{73}$ 69-76 Currently, riociguat is the only pharmacotherapy to be approved for the treatment of two $\mathrm{PH}$ indications, $\mathrm{PAH}$ and chronic thromboembolic PH (CTEPH). ${ }^{14-16}$ Riociguat is approved in the USA, Europe and several other regions for patients with group I PAH in WHO FC II or III; and for the treatment of patients with inoperable CTEPH, or persistent/recurrent $\mathrm{PH}$ after pulmonary endarterectomy in WHO FC II or III. Patients receiving riociguat have their dose individually adjusted up to the optimal dose over a period of 8 weeks, according to the patient's systolic systemic arterial blood pressure and signs or symptoms of hypotension.

Riociguat and PDE5 inhibitors act on separate targets within the NO signalling pathway. Combining them may increase the risk of amplifying their effects, leading to systemic hypotension. Therefore, the use of PDE5 inhibitors in conjunction with riociguat is contraindicated. ${ }^{14-16} 77$ Rare cases of haemoptysis have been reported with riociguat therapy in patients with $\mathrm{PAH}$ and CTEPH. Details of the PATENT-1 study and its long-term extension PATENT-2 are given in tables 3 and 4.

\section{Combination therapy}

Combining two or more classes of agent is a strategy that has been used successfully in the treatment of many other cardiovascular conditions such as systemic hypertension and heart failure. ${ }^{17}$ Combination therapy can be given as first-line treatment or by sequentially adding drugs to a patient's treatment regimen. The 2013 updated algorithm of PAH treatment from the 5th World Symposium on PH recommends sequential combination therapy, due to the high level of evidence of efficacy, in patients with $\mathrm{PAH}$ with an inadequate response to monotherapy, and possible first-line combination therapy in WHO FC III and IV patients with a lower recommendation. ${ }^{17}$ Several clinical trials have now assessed the effect of combination therapy in patients with $\mathrm{PAH}$, with mixed results (see below). Several recent meta-analyses of the efficacy of combination therapy versus monotherapy, however, conclude that combination therapy can improve clinical outcomes, but has no proven effect on mortality. ${ }^{78-81}$ However, all acknowledge that more data are required from further studies.

\section{First-line combination therapy}

There are few data available on the use of combination therapy as a first-line treatment. The BREATHE- $2^{82}$ study investigated the effect of combined treatment with bosentan and epoprostenol versus epoprostenol and placebo in a small group of 33 patients with severe PAH (WHO FC III and IV) over 16 weeks, but did not demonstrate a significant difference between the two treatments in the primary endpoint of total pulmonary resistance. Three deaths were reported, all in the bosentan arm; however, investigators concluded that they reflected the severity and progressive nature of PAH and were not related to study treatment.

First-line combination therapy with ambrisentan and tadalafil was evaluated in the randomised, multicentre AMBITION study. ${ }^{83} 84$ This study had a dual placebo design, with one placebo group receiving ambrisentan monotherapy with placebo tadalafil, while the second placebo group received tadalafil monotherapy with placebo ambrisentan. With 610 patients enrolled, and followed up for up to 3.5 years, ${ }^{84}$ AMBITION was a considerably larger trial than the pioneer BREATHE-2 study. Significant improvements were seen in the composite primary endpoint of morbidity/mortality in the combination group compared with the pooled monotherapy arms, which were driven by differences in hospitalisation. Hierarchical testing of secondary endpoints showed significant improvements in $N$-terminal prohormone of brain natriuretic peptide (NT-proBNP), proportion of patients with satisfactory clinical response, and 6MWD. No important safety signals were observed. At the time of writing, the results of the AMBITION trial have only been presented in abstract form and have not yet been published. ${ }^{83}$

\section{Sequential combination therapy}

Several studies have evaluated the efficacy of adding a new therapy to a patient's existing PAH treatment regimen, with variable results (figure 2).

The addition of sildenafil or riociguat to prostanoid treatment has proved successful. The PACES study investigated the addition of sildenafil $80 \mathrm{mg}$ three times daily (four times the 


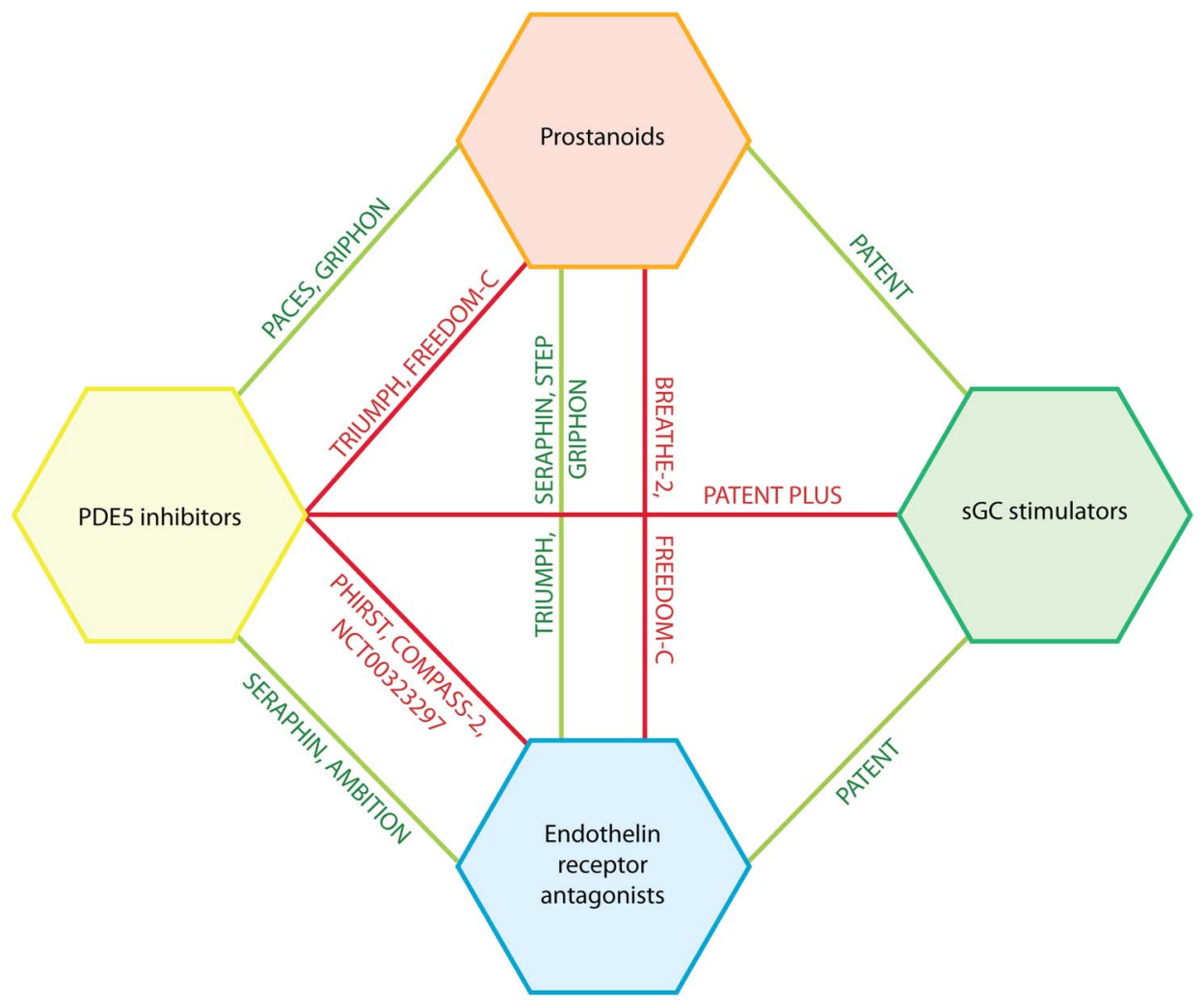

Figure 2 Combination therapy strategies tested in randomised controlled clinical trials. ERA, endothelin receptor antagonist; PDE5, phosphodiesterase type 5; sGC, soluble guanylate cyclase.

approved dose) to the treatment of 267 patients with $\mathrm{PAH}$ already receiving epoprostenol. ${ }^{85}$ After 16 weeks of treatment, improvements were seen in $6 \mathrm{MWD}$, mean pulmonary arterial pressure, cardiac output, time to clinical worsening (TTCW) and quality of life (QoL) compared with placebo. Adverse events (AEs) observed more often with sildenafil treatment were headache and dyspepsia. ${ }^{85}$ PATENT-1 ${ }^{31}$ investigated the efficacy and safety of riociguat as combination therapy and monotherapy. Of 443 patients, 222 were receiving ERAs $(n=194)$ or nonintravenous prostanoids $(n=28)$. Overall, after 12 weeks of treatment, 6MWD, PVR, NT-proBNP, WHO FC, TTCW, QoL and Borg dyspnoea score were significantly improved. Riociguat was effective in combination therapy and as monotherapy. The most common AEs that occurred during the study were headache, dyspepsia and peripheral oedema. ${ }^{31}$

Macitentan has been shown to be effective in patients already receiving either non-intravenous prostanoids or PDE5 inhibitors. The SERAPHIN study ${ }^{28}$ investigated whether long-term treatment with macitentan reduced a combined endpoint of morbidity or mortality in patients with $\mathrm{PAH}$ as either combination or monotherapy over 3 years. ${ }^{86}$ Of 742 patients treated, 471 were receiving either PDE5 inhibitors $(n=454)$ or nonintravenous prostanoids $(n=40)$. Overall, there was a significant reduction in the risk of a combined endpoint event in patients
Trials not demonstrating significant benefit

*FREEDOM-C - ERAs/non-intravenous prostanoids + oral treprostinil ${ }^{91}$

*TRIUMPH - sildenafil + inhaled treprostinil ${ }^{21}$

*PHIRST - bosentan + tadalafi ${ }^{30}$

COMPASS-2 - sildenafil + bosentan ${ }^{87}$

NCT00323297 - bosentan + sildenafil ${ }^{88}$

BREATHE-2 - epoprostenol + bosentan ${ }^{82}$

PATENT PLUS - sildenafil + riociguat $^{77}$

* Subgroup analyses receiving macitentan compared with placebo, which was driven by deterioration in PAH. The risk of a combined endpoint event for patients receiving macitentan as monotherapy was lower than for patients receiving macitentan in combination therapy. However, patients receiving combination therapy showed a significant improvement in $6 \mathrm{MWD}$, whereas patients receiving macitentan monotherapy did not. Nasopharyngitis, headache and anaemia were more common in patients receiving macitentan than in those receiving placebo. ${ }^{28}$

The efficacy of adding bosentan to other therapies has not been proven, despite its evaluation in several studies. In the phase IV, event-driven COMPASS- $2^{87}$ study, 334 patients receiving sildenafil for at least 12 weeks were randomised to either placebo or bosentan. The primary endpoint of time to the first morbidity/mortality event (defined as death, hospitalisation for $\mathrm{PAH}$ worsening or intravenous prostanoid initiation, atrial septostomy, lung transplant, or worsening PAH) was not met, with a non-significant observed risk reduction for morbidity/mortality. Improvements were observed in secondary endpoints 6MWD and NT-proBNP. The safety profile was consistent with that of bosentan, with no new signals observed. ${ }^{87}$

In a study design that was essentially a reversal of COMPASS-2, NCT00323297 ${ }^{88}$ investigated the addition of sildenafil to the treatment of 103 patients with $\mathrm{PAH}$ already 
receiving bosentan. The trial did not meet its primary endpoint of a significant increase in 6MWD in patients treated with combined bosentan and sildenafil compared with patients treated with bosentan alone. The most common AEs in the sildenafil group were diarrhoea, headache and peripheral oedema. ${ }^{88}$

The addition of riociguat on top of bosentan therapy has been efficacious in PATENT- $1 .{ }^{31}$ However, the STEP ${ }^{89}$ study investigating the addition of inhaled iloprost to bosentan treatment in patients with PAH $(n=67)$ showed a numerically greater $6 \mathrm{MWD}$ in the inhaled iloprost plus bosentan group compared with bosentan alone at 12 weeks. While this trend did not reach statistical significance, there were significant improvements in WHO FC, TTCW, mean pulmonary artery pressure and PVR. The most frequently reported AEs in the iloprost group were consistent with the safety profile of prostanoids, and included headache, flushing and jaw pain. ${ }^{89}$

The PHIRST study ${ }^{30}$ investigated tadalafil as monotherapy or in combination therapy, with bosentan in 405 patients. After 16 weeks, improvement in 6MWD in patients receiving tadalafil as monotherapy was significant, whereas that of patients receiving combination therapy was not. The most common treatment-related AEs reported with tadalafil were headache, myalgia and flushing. ${ }^{30}$

COMPASS $-3^{90}$ was a study investigating the benefits of a stepped approach to combination therapy. One hundred treatment-naïve patients started receiving bosentan for 16 weeks. If they failed to achieve a $6 \mathrm{MWD} \geq 380 \mathrm{~m}$ by week 16, they were given sildenafil in addition to bosentan. At the end of the trial, $31 \%$ of patients had achieved the $\geq 380 \mathrm{~m}$ threshold (16\% on monotherapy and $15 \%$ on combination therapy). No statistical analysis is available. The most common reported AEs were peripheral oedema, dyspnoea, headache, dizziness, anaemia and abnormal liver function tests. ${ }^{90}$

There is some evidence that the delivery route of a drug may influence its efficacy in combination with other drugs. The TRIUMPH study ${ }^{21}$ investigated the effect of adding inhaled treprostinil to the therapy regimen of 235 patients with PAH who were receiving bosentan or sildenafil. After 12 weeks, there were significant improvements in 6MWD, QoL and NT-proBNP, but not in TTCW or WHO FC. AEs associated with treprostinil treatment were cough, headache and flushing. ${ }^{21}$ Conversely, the addition of oral treprostinil to similar background therapy as TRIUMPH was not successful. The FREEDOM-C study ${ }^{91}$ investigated the effect of adding oral treprostinil to the regimen of 350 patients receiving ERAs and/ or PDE5 inhibitors. After 16 weeks, the primary endpoint, improvement in $6 \mathrm{MWD}$, did not reach significance. AEs that resulted in study drug discontinuation included headache, nausea, diarrhoea, vomiting, worsening $\mathrm{PH}$, extremity pain, chest discomfort and myalgia. ${ }^{91}$

The background therapy of a patient may also influence the choice of add-on treatment. For patients who are already receiving PDE5 inhibitors, riociguat is contraindicated. The phase II PATENT-PLUS ${ }^{77}$ study investigated the safety and clinical effect of riociguat in combination with sildenafil in 18 patients. After 12 weeks, combination therapy showed no favourable effects on exploratory clinical parameters, including haemodynamics and 6MWD. The primary endpoint of the trial, change from baseline in supine systolic blood pressure versus placebo, did not show a difference between riociguat and placebo. There were unfavourable safety signals (high rates of discontinuation due to hypotension and SAEs) with sildenafil plus riociguat in the longterm, single-arm, open-label phase of the study and no evidence of a positive benefit:risk ratio. ${ }^{77}$

\section{CONCLUSIONS}

The pathobiology of PAH is complex, and it is necessary for prescribing clinicians to have a thorough understanding of the mode of action of the drugs available for PAH and of the evidence base of various combinations. The approval of riociguat has introduced a new, fourth class of pharmacotherapy, targeting the NO-sGC-cGMP pathway with a different molecular target to previously approved PDE5 inhibitors. However, comparative studies of the approved classes of therapy are lacking. Although more evidence from trials of various therapies in combination is becoming available, the benefits of many therapy combinations remain inconclusive. The question of sequential versus first-line combination therapy is still under investigation, with further studies warranted. Combination therapy according to patient phenotype will also need to be guided by future studies. Despite the advances made in recent years, PAH remains an incurable disease and as such, there is still an unmet medical need for new therapies, possibly targeting alternative pathways.

Funding Editorial assistance, provided by Adelphi Communications Ltd (Bollington, UK), was sponsored by Bayer Pharma AG.

Competing interests $\mathrm{MH}$ has received consultancy fees from Actelion, Bayer, GSK, Novartis, Pfizer and Aires. He has received speaker fees from Actelion, Bayer, GSK, Novartis and Pfizer. H-AG has received consultancy fees from Actelion, Bayer, Ergonex, Gilead, GSK, Merck, Novartis and Pfizer. He has received speaker fees from Actelion, Bayer, Ergonex, Gilead, GSK, Novartis and Pfizer.

Provenance and peer review Not commissioned; externally peer reviewed.

Open Access This is an Open Access article distributed in accordance with the Creative Commons Attribution Non Commercial (CC BY-NC 4.0) license, which permits others to distribute, remix, adapt, build upon this work non-commercially, and license their derivative works on different terms, provided the original work is properly cited and the use is non-commercial. See: http://creativecommons.org/ licenses/by-nc/4.0/

\section{REFERENCES}

1 Simonneau G, Gatzoulis MA, Adatia I, et al. Updated clinical classification of pulmonary hypertension. J Am Coll Cardiol 2013;62:D34-41.

2 Voelkel NF, Gomez-Arroyo J, Abbate A, et al. Pathobiology of pulmonary arterial hypertension and right ventricular failure. Eur Respir J 2012;40:1555-65

3 McLaughlin VV, Archer SL, Badesch DB, et al. ACCF/AHA 2009 expert consensus document on pulmonary hypertension: a report of the American College of Cardiology Foundation Task Force on Expert Consensus Documents and the American Heart Association: developed in collaboration with the American College of Chest Physicians, American Thoracic Society, Inc., and the Pulmonary Hypertension Association. Circulation 2009;119:2250-94.

4 Farber HW, Loscalzo J. Pulmonary arterial hypertension. N Engl J Med 2004;351:1655-65

5 Morrell NW, Adnot S, Archer SL, et al. Cellular and molecular basis of pulmonary arterial hypertension. J Am Coll Cardiol 2009;54(1 Suppl):S20-31.

6 Humbert M, Sitbon 0, Simonneau G. Treatment of pulmonary arterial hypertension. N Engl J Med 2004;351:1425-36.

7 Humbert M, Morrell NW, Archer SL, et al. Cellular and molecular pathobiology of pulmonary arterial hypertension. J Am Coll Cardiol 2004;43:13S-24S.

8 Humbert M. Pulmonary arterial hypertension and chronic thromboembolic pulmonary hypertension: pathophysiology. Eur Respir Rev 2010;19:59-63.

9 Humbert M, Lau EM, Montani D, et al. Advances in therapeutic interventions for patients with pulmonary arterial hypertension. Circulation 2014;130:2189-208.

10 Benza RL, Miller DP, Barst RJ, et al. An evaluation of long-term survival from time of diagnosis in pulmonary arterial hypertension from REVEAL. Chest 2012;142:448-56.

11 Humbert M, Sitbon 0 , Chaouat $A$, et al. Survival in patients with idiopathic, familial, and anorexigen-associated pulmonary arterial hypertension in the modern management era. Circulation 2010;122:156-63.

12 Humbert $M$, Sitbon 0 , Yaici $A$, et al. Survival in incident and prevalent cohorts of patients with pulmonary arterial hypertension. Eur Respir J 2010;36:549-55.

13 Conole D, Scott LJ. Riociguat: first global approval. Drugs 2013;73:1967-75.

14 Adempas ${ }^{\circledR}$ US prescribing information. 2013. http://labelingbayerhealthcare.com/ html/products/pi/Adempas_PI.pdf

15 Bayer Pharma AG. Adempas ${ }^{\circledR}$ Canadian prescribing information. 2013. http://www. bayer.ca/files/ADEMPAS-PM-EN-17Sep2013-162761.pdf 
16 Bayer Pharma AG. Adempas® (riociguat tablets): EU summary of product characteristics. 2014. http://www.ema.europa.eu/docs/en_GB/document_library/ EPAR_-_Product_Information/human/002737/WC500165034.pdf

17 Galiè N, Corris PA, Frost A, et al. Updated treatment algorithm of pulmonary arterial hypertension. J Am Coll Cardiol 2013;62:D60-72.

18 Taichman DB, Ornelas J, Chung L, et al. Pharmacological therapy for pulmonary arterial hypertension in adults: CHEST guideline. Chest 2014;146:449-75.

19 Rubin LJ, Mendoza J, Hood M, et al. Treatment of primary pulmonary hypertension with continuous intravenous prostacyclin (epoprostenol). Results of a randomized trial. Ann Intern Med 1990;112:485-91.

20 Simonneau G, Barst RJ, Galie N, et al. Continuous subcutaneous infusion of treprostinil, a prostacyclin analogue, in patients with pulmonary arterial hypertension: a double-blind, randomized, placebo-controlled trial. Am J Respir Crit Care Med 2002;165:800-4

21 McLaughlin VV, Benza RL, Rubin LJ, et al. Addition of inhaled treprostinil to oral therapy for pulmonary arterial hypertension: a randomized controlled clinical trial. J Am Coll Cardiol 2010;55:1915-22.

22 Jing ZC, Parikh K, Pulido T, et al. Efficacy and safety of oral treprostinil monotherapy for the treatment of pulmonary arterial hypertension: a randomized, controlled trial. Circulation 2013;127:624-33.

23 Olschewski H, Simonneau G, Galie N, et al. Inhaled iloprost for severe pulmonary hypertension. N Engl J Med 2002;347:322-9.

24 Galie N, Humbert M, Vachiery JL, et al. Effects of beraprost sodium, an oral prostacyclin analogue, in patients with pulmonary arterial hypertension: a randomized, double-blind, placebo-controlled trial. J Am Coll Cardiol 2002;39:1496-502.

25 Rubin LJ, Badesch DB, Barst RJ, et al. Bosentan therapy for pulmonary arterial hypertension. N Engl J Med 2002;346:896-903.

26 Galiè N, Rubin L, Hoeper $M$, et al. Treatment of patients with mildly symptomatic pulmonary arterial hypertension with bosentan (EARLY study): a double-blind, randomised controlled trial. Lancet 2008;371:2093-100.

27 Galiè N, Olschewski H, Oudiz RJ, et al. Ambrisentan for the treatment of pulmonary arterial hypertension: results of the ambrisentan in pulmonary arterial hypertension, randomized, double-blind, placebo-controlled, multicenter, efficacy (ARIES) study 1 and 2. Circulation 2008;117:3010-19.

28 Pulido T, Adzerikho I, Channick RN, et al. Macitentan and morbidity and mortality in pulmonary arterial hypertension. N Engl J Med 2013;369:809-18.

29 Galiè N, Ghofrani HA, Torbicki A, et al. Sildenafil citrate therapy for pulmonary arterial hypertension. N Engl J Med 2005;353:2148-57.

30 Galiè N, Brundage BH, Ghofrani HA, et al. Tadalafil therapy for pulmonary arterial hypertension. Circulation 2009;119:2894-903

31 Ghofrani HA, Galiè N, Grimminger F, et al. Riociguat for the treatment of pulmonary arterial hypertension. N Engl J Med 2013;369:330-40.

32 McGoon MD, Frost AE, Oudiz RJ, et al. Ambrisentan therapy in patients with pulmonary arterial hypertension who discontinued bosentan or sitaxsentan due to liver function test abnormalities. Chest 2009;135:122-9.

33 Rubin LJ, Badesch DB, Fleming TR, et al. Long-term treatment with sildenafil citrate in pulmonary arterial hypertension: SUPER-2. Chest 2011;140:1274-83.

34 Oudiz RJ, Brundage BH, Galie N, et al. Tadalafil for the treatment of pulmonary arterial hypertension: a double-blind 52-week uncontrolled extension study. J Am Coll Cardiol 2012:60:768-74.

35 Rubin LJ, Galie N, Grimminger F, et al. Riociguat for the treatment of pulmonary arterial hypertension: a long-term extension study (PATENT-2). Eur Respir J 2015;45:1303-13.

36 Gryglewski RJ. Prostacyclin among prostanoids. Pharmacol Rep 2008;60:3-11.

37 Blindt $R$, Bosserhoff $A K$, vom Dahl J, et al. Activation of IP and EP(3) receptors alters CAMP-dependent cell migration. Eur J Pharmacol 2002;444:31-7.

38 Wharton J, Davie N, Upton PD, et al. Prostacyclin analogues differentially inhibit growth of distal and proximal human pulmonary artery smooth muscle cells. Circulation 2000;102:3130-6.

39 Wallerstedt SM, Bodelsson M. Endothelium-dependent relaxation by substance $P$ in human isolated omental arteries and veins: relative contribution of prostanoids, nitric oxide and hyperpolarization. Br J Pharmacol 1997;120:25-30.

40 Vane J, Corin RE. Prostacyclin: a vascular mediator. Eur J Vasc Endovasc Surg 2003:26:571-8.

41 Li RC, Cindrova-Davies T, Skepper JN, et al. Prostacyclin induces apoptosis of vascular smooth muscle cells by a cAMP-mediated inhibition of extracellular signal-regulated kinase activity and can counteract the mitogenic activity of endothelin-1 or basic fibroblast growth factor. Circ Res 2004;94:759-67.

42 Kothapalli D, Stewart SA, Smyth EM, et al. Prostacylin receptor activation inhibits proliferation of aortic smooth muscle cells by regulating CAMP response element-binding protein- and pocket protein-dependent cyclin a gene expression. Mol Pharmacol 2003;64:249-58.

43 Christman BW, Mcpherson CD, Newman JH, et al. An imbalance between the excretion of thromboxane and prostacyclin metabolites in pulmonary-hypertension. N Engl J Med 1992;327:70-5.

44 Tuder RM, Cool CD, Geraci MW, et al. Prostacyclin synthase expression is decreased in lungs from patients with severe pulmonary hypertension. Am J Respir Crit Care Med 1999;159:1925-32.
45 Barst R. How has epoprostenol changed the outcome for patients with pulmonary arterial hypertension? Int J Clin Pract Supp/ 2010;64:23-32.

46 McLaughlin VV, Shillington A, Rich S. Survival in primary pulmonary hypertension: the impact of epoprostenol therapy. Circulation 2002;106:1477-82.

47 Barst RJ, McGoon M, McLaughlin V, et al. Beraprost therapy for pulmonary arterial hypertension. J Am Coll Cardiol 2003;41:2119-25.

48 Simonneau G, Torbicki A, Hoeper MM, et al. Selexipag: an oral, selective prostacyclin receptor agonist for the treatment of pulmonary arterial hypertension. Eur Respir J 2012;40:874-80.

49 Actelion. Selexipag. 2014. http://www.1actelion.com/en/scientists/ development-pipeline/phase-3/selexipagpage

50 McLaughlin VV, Channick R, Chin KM, et al. Effect of selexipag on morbidity/ mortality in pulmonary arterial hypertension: results of the GRIPHON study. J Am Coll Cardiol 2015;65.

51 Davie N, Haleen SJ, Upton PD, et al. ETA and ETB receptors modulate the proliferation of human pulmonary artery smooth muscle cells. Am J Respir Crit Care Med 2002;165:398-405.

52 Giaid A, Yanagisawa M, Langleben D, et al. Expression of endothelin-1 in the lungs of patients with pulmonary hypertension. N Engl J Med 1993;328:1732-9.

53 Rubin L. Endothelin receptor antagonists for the treatment of pulmonary artery hypertension. Life Sci 2012;91:517-21.

54 Frumkin LR. The pharmacological treatment of pulmonary arterial hypertension. Pharmacol Rev 2012;64:583-620.

55 Seo B, Oemar BS, Siebenmann R, et al. Both ETA and ETB receptors mediate contraction to endothelin-1 in human blood vessels. Circulation 1994;89:1203-8.

56 Hirata Y, Emori T, Eguchi S, et al. Endothelin receptor subtype B mediates synthesis of nitric oxide by cultured bovine endothelial cells. J Clin Invest 1993;91:1367-73.

57 Eguchi S, Hirata Y, Marumo F. Endothelin subtype B receptors are coupled to adenylate cyclase via inhibitory $\mathrm{G}$ protein in cultured bovine endothelial cells. J Cardiovasc Pharmacol 1993;22(Suppl 8):S161-3

58 Humbert M, Segal ES, Kiely DG, et al. Results of European post-marketing surveillance of bosentan in pulmonary hypertension. Eur Respir J 2007;30:338-44.

59 Opitz CF, Ewert R, Kirch W, et al. Inhibition of endothelin receptors in the treatment of pulmonary arterial hypertension: does selectivity matter? Eur Heart $J$ 2008;29:1936-48.

60 Seferian A, Simonneau G. Therapies for pulmonary arterial hypertension: where are we today, where do we go tomorrow? Eur Respir Rev 2013;22:217-26.

61 Cardillo C, Kilcoyne CM, Waclawiw M, et al. Role of endothelin in the increased vascular tone of patients with essential hypertension. Hypertension 1999;33:753-8.

62 Oudiz RJ, Galiè N, Olschewski H, et al. Long-term ambrisentan therapy for the treatment of pulmonary arterial hypertension. J Am Coll Cardiol 2009;54:1971-81.

63 Kass DA, Takimoto E, Nagayama T, et al. Phosphodiesterase regulation of nitric oxide signaling. Cardiovasc Res 2007:75:303-14.

64 Corbin JD, Beasley A, Blount MA, et al. High lung PDE5: a strong basis for treating pulmonary hypertension with PDE5 inhibitors. Biochem Biophys Res Commun 2005:334:930-8.

65 Murray F, MacLean MR, Pyne NJ. Increased expression of the cGMP-inhibited CAMP-specific (PDE3) and CGMP binding CGMP-specific (PDE5) phosphodiesterases in models of pulmonary hypertension. Br J Pharmacol 2002;137:1187-94.

66 Nagendran J, Archer SL, Soliman D, et al. Phosphodiesterase type 5 is highly expressed in the hypertrophied human right ventricle, and acute inhibition of phosphodiesterase type 5 improves contractility. Circulation 2007;116:238-48.

67 Corbin JD, Francis SH. Molecular biology and pharmacology of PDE-5-inhibitor therapy for erectile dysfunction. J Androl 2003;24:S38-41.

68 Galiè N, Hoeper MM, Humbert M, et al. Guidelines for the diagnosis and treatment of pulmonary hypertension: the task force for the diagnosis and treatment of pulmonary hypertension of the European Society of Cardiology (ESC) and the European Respiratory Society (ERS), endorsed by the international society of heart and lung transplantation (ISHLT). Eur Heart J 2009;30:2493-537.

69 Stasch JP, Pacher P, Evgenov OV. Soluble guanylate cyclase as an emerging therapeutic target in cardiopulmonary disease. Circulation 2011;123:2263-73.

70 Zhao L, Mason NA, Strange JW, et al. Beneficial effects of phosphodiesterase 5 inhibition in pulmonary hypertension are influenced by natriuretic peptide activity. Circulation 2003;107:234-7.

71 Ignarro LJ, Buga GM, Wood KS, et al. Endothelium-derived relaxing factor produced and released from artery and vein is nitric oxide. Proc Natl Acad Sci USA 1987:84:9265-9.

72 Arnold WP, Mittal CK, Katsuki S, et al. Nitric oxide activates guanylate cyclase and increases guanosine $3^{\prime}: 5^{\prime}$-cyclic monophosphate levels in various tissue preparations. Proc Natl Acad Sci USA 1977;74:3203-7.

73 Stasch JP, Evgenov OV. Soluble guanylate cyclase stimulators in pulmonary hypertension. Handb Exp Pharmacol 2013;218:279-313.

74 Follmann M, Griebenow N, Hahn MG, et al. The chemistry and biology of soluble guanylate cyclase stimulators and activators. Angew Chem Int Ed Engl 2013;52:9442-62.

75 Schermuly RT, Stasch JP, Pullamsetti SS, et al. Expression and function of soluble guanylate cyclase in pulmonary arterial hypertension. Eur Respir J 2008; 32:881-91. 
76 Stasch JP, Hobbs AJ. NO-independent, haem-dependent soluble guanylate cyclase stimulators. Handb Exp Pharmacol 2009;191:277-308.

77 Galie N, Muller K, Scalise AV, et al. PATENT PLUS: a blinded, randomised and extension study of riociguat plus sildenafil in pulmonary arterial hypertension. Eur Respir J 2015;45:1314-22.

78 Coeytaux RR, Schmit KM, Kraft B, et al. Comparative effectiveness and safety of drug therapy for pulmonary arterial hypertension: a systematic review and meta-analysis. Chest 2014;145:1055-63.

79 Fox BD, Shimony A, Langleben D. Meta-analysis of monotherapy versus combination therapy for pulmonary arterial hypertension. Am J Cardiol 2011;108:1177-82.

80 Bai Y, Sun L, Hu S, et al. Combination therapy in pulmonary arterial hypertension: a meta-analysis. Cardiology 2011;120:157-65.

81 Manes A, Palazzini M, Tremblay G, et al. Combination therapy for pulmonary arterial hypertension (PAH) reduces consistently clinical worsening as compared to monotherapy: an updated meta-analysis of randomized controlled trials. Eur Heart $\int$ 2014;35 (Abstract supplement).

82 Humbert M, Barst RJ, Robbins IM, et al. Combination of bosentan with epoprostenol in pulmonary arterial hypertension: BREATHE-2. Eur Respir / 2004;24:353-9.

83 Galiè N. The AMBITION study: design and results. Eur Respir J 2014:44.

84 GlaxoSmithKline. A Study of First-Line Ambrisentan and Tadalafil Combination Therapy in Subjects With Pulmonary Arterial Hypertension (PAH) (AMBITION). 2015. https://linicaltrials.gov/ct2/show/NCT01178073
85 Simonneau G, Rubin LJ, Galie N, et al. Addition of sildenafil to long-term intravenous epoprostenol therapy in patients with pulmonary arterial hypertension: a randomized trial. Ann Intern Med 2008;149:521-30.

86 Actelion. Study of macitentan (ACT-064992) on morbidity and mortality in patients with symptomatic pulmonary arterial hypertension. 2015. https://linicaltrials.gov/ ct2/show/NCT00660179

87 McLaughlin V, Channick R, Ghofrani H-A, et al. Effect of bosentan and sildenafil combination therapy on morbidity and mortality in pulmonary arterial hypertension (PAH): results from the COMPASS-2 study. Chest 2014;146:860A.

88 Pfizer. Assess the efficacy and safety of sildenafil when added to bosentan in the treatment of pulmonary arterial hypertension. 2014. https://clinicaltrials.gov/ct2/ show/study/NCT00323297

89 McLaughlin VV, Oudiz RJ, Frost A, et al. Randomized study of adding inhaled iloprost to existing bosentan in pulmonary arterial hypertension. Am J Respir Crit Care Med 2006;174:1257-63.

90 Benza RL, Gupta H, Soto FJ, et al. Safety and efficacy of bosentan in combination with sildenafil in PAH patients who experience inadequate clinical response to monotherapy: the COMPASS-3 Study. Chest 2010;138.

91 Tapson VF, Torres F, Kermeen F, et al. Oral treprostinil for the treatment of pulmonary arterial hypertension in patients on background endothelin receptor antagonist and/or phosphodiesterase type 5 inhibitor therapy (the FREEDOM-C study): a randomized controlled trial. Chest 2012;142:1383-90. 